\title{
Status, Trends, and Potentials of Turtle Conservation in Bali: A Mini Review
}

\author{
Yesha Ainesis El Gracianita Pelupessy ${ }^{1}$, Putu Angga Wiradana ${ }^{1 *}$, I Wayan Rosiana ${ }^{1}$, \\ I Gede Widhiantara ${ }^{1}$ \\ ${ }^{1}$ Study Program of Biology, Faculty of Health, Science and Technology, Universitas Dhyana Pura, Jalan Raya \\ Padangluwih, North Kuta, Badung, Bali, Indonesia. \\ *Corresponding author: angga.wiradana@undhirabali.ac.id
}

\begin{abstract}
Sea turtles in Bali has been exploited excessively, which caused decrease in population, and this issue has placed sea turtles threatened to extinction. This review article aimed to provide information regarding the status, trends, and potential of sea turtles in Bali. Information given in this article is vital to ensure reliable knowledge not to only understand our current situation, but also to increase efficiency in reliant to the problem sea turtles face. The literature study method is used to write this review paper, namely by accessing a number of research paper published nationally and internationally. It was explained that the status of sea turtles is known to be endangered and law enforcement is not sufficient overcoming the problem. Conservation trends such as nurturing hatchlings have shown to not only help restore the population of sea turtles, but also to bring economic benefits to the conservation sites and the people. Potentials of ecotourism and DNA Barcoding has shown to be effective to benefit the people economically and increase the efficiency of law enforcement and conservation. Solutions and methods of improvement such as ecotourism and DNA Barcoding explained in this article is practical for Bali to adapt, so that sea turtle conservation is capable to overcome its status and incline to its potential.
\end{abstract}

Keywords: conservation, sea turtles, ecotourism, DNA barcoding, Bali

Received: 27 Juni 2021

Revised: 15 Agustus 2021

Accepted: 16 September 2021

\section{INTRODUCTION}

Indonesia is a tropical country that consists of more than 17,500 islands along the equator with a sea area exceeding 360 million hectares. Indonesia also lies between the isothermal $20^{\circ} \mathrm{LU} / \mathrm{LS}$, which indicates an ideal location to support the growth of various biodiversities, one of which is sea turtles. Sea turtles are marine reptiles that are capable of migrating long distances along the Indian Ocean, Pacific Ocean and Southeast Asia(Luschi, 2013). It is known that there are 7 types of sea turtles around the world (Robinson \& Paladino, 2013) and 6 of them are in Indonesia (Ario et al., 2016).

The last few decades have shown a continuous decrease regarding the population of sea turtles which caused it to be endagered (Mazaris et al., 2017). Therefore, sea turtles have become one of the most protected fauna globally. There are several threats sea turtles face, biological and human threats (Hamann et al., 2010). Biologically, wild hatchlings have faced death threats from predatory animals such as crabs, birds and other reptiles. Regardless of the biological threat, humans are the main reason responsible for the population downturn of sea turtles (Guebert et al., 2013). Human threats such as, over-development of coastal areas (Hill et al., 2019), waste dump (Rice et al., 2021), illegal catching of turtle eggs (Williams, 2021), meat and shells for years have caused sea turtles to become endangered (Espinoza et al., 2021).

Due to the situation given, humans are moved to implement wildlife conservation programs. These programes are expected to prevent and stop the mass extinction of wild sea turtles, its habitat, and the use of turtles for commercial purposes such as selling eggs, meat and shells. Conservation programs are educational regarding the purpose of the program itself and the importance of sea turtles (Mazaris et al., 2017). Protecting turtle eggs have become one of the main conservation 
programs. Because of this program, during 2016 to 2019, egg production has increased significantly from 6,602 to 23,400 eggs (Adi Eti Harnino et al., 2021). This amount surely is significant in restoring the population of sea turtles.

Sea turtle conservation in Indonesia, especially ecotourism, has great potential. Ecotourism increases opportunities for more future conservation programs as well as raising awareness in order to restore the habitat of sea turtles damaged by humans (Tisdell \& Wilson, 2002). Ario et al., (2016) and Maharani et al., (2016) conducted a research that supports the statement given. Their research shows positive results in increasing public awareness by expanding ecotourism in Indonesia. Ecotourism is vital in conservation to ensure a sufficient protection of sea turtles, while the local community is economically weak (Stronza et al., 2019). The potentials of sea turtle conservation is dependent on activities and programs utilized to attract the public. The usage of sea turtles as tourist attraction is an alternative solution to have more resources to protect sea turtles and provide economic benefits (Wilson \& Tisdell, 2003). These potentials will be a stepping stone to strengthen the implementation preservation, conservation and protection of sea turtles in all regions of Indonesia.

The continuous decrease of sea turtle population in Bali reveals the efficiency of turtle conservation is not at its optimal level due to lack of information regarding the problem of sea turtles in this province in a course of 5 to 10 years. In order to maintain the population of sea turtles is to maintain all possible habitat and nesting areas of this marine species in Bali. The knowledge derived from this article is to fill this lack of information. Knowing the conditions and situation sea turtles are experiencing in Bali will alter or create solutions to overcome the problem.

This review aims to provide new information regarding the status, trends and potential of sea turtle conservation in Bali. It is expected to contribute knowledge related to the bioconservation of wildlife in Indonesia that can be carried out wisely by the community, academics, practitioners, related conservation institutions, and the government in making policies in the field of animal welfare.

\section{MATERIALS AND METHODS}

This review article was written using the literature study method, namely by collecting and accessing a number of scientific articles published nationally and internationally, books, databases such as Science Direct, WileyBlackwell, Springer Nature, Google Scholar, NCBI, ResearchGate and PubMed (Wiradana et al., 2021) using keywords such as hatching process, hatching life turtle, Turtle Conservation, Nesting area, and population abundance and trends in Bali.

\section{RESULTS AND DISCUSSIONS}

\section{Status of Sea Turtles in Indonesia}

Sea turtles are marine migrating species that spend most of its life below sea level. Sea Turtles are considered rare marine biota and its protection is recorded in Indonesian legislation (Astiani et al., 2017). Six out of seven species of sea turtles are found in Indonesian waters, these six species include green turtle (Chelonia mydas), hawksbill turtle (Eretmochelys imbricata), gray turtle (Lepidochelys olivacea), flat turtle (Natator depressus), leatherback turtle (Dermochelys coricea), and loggerhead turtle (Carreta carreta) (Pardede \& Yealta, 2013; Suraeda et al., 2018).

Sea turtles are now endangered due to the decrease in population. This status is caused by various threats in which the main threat is manmade. In addition, one other crucial factors affected by a predator during the hatching period. It has been reported that sea turtle eggs have been stolen to be sold and eaten. It is for a fact, without the ability to produce, decrease in population of sea turtles are inevitable. Other forms of threats include exploitation of turtles to meet protein needs for some local communities, slaughtering turtles during traditional ceremonies, processing turtles into various 
products from food to cosmetics and handicrafts, as well as capturing turtles for hatchlings, meat, skin, and shells (Adi Eti Harnino et al., 2021; Ginting et al., 2020; Sudiana, 2010).

Habitat disturbance that causes decrease in turtle population is excessive development of coastal areas that directly reduce the habitat for turtles to nest (Mazaris et al., 2009). Currently, all turtle species have been listed in Appendix I List of CITES (Convention on International Trade of Endangered Species). This convention prohibits all international trade activities for all products derived from turtles, whether in the form of eggs, meat or shells (Alfinda, 2017; Mansula \& Romadhon, 2020).

Green turtles are one of the species of sea turtles in Indonesian waters threatened with extinction (Prihadi et al., 2018). These sea turtles are exploited massively by humans, IUCN in 1987 reports an incident estimated that every year as many as 30,000 turtles are caught from all beaches where turtles lay eggs in Indonesia. The report resulted in the world's animal lover organization threatening Indonesia (Bali) as the country for the largest turtle slaughtering. This is one of the biggest consequences of this species being classified as an endangered species in the International Union for Conservation of Nature (IUCN) Red List, namely species that are at risk of extinction in the near future (Ayuningtyas $e t$ al., 2019; Sudiana, 2010).

Through this pressure Sudiana (2010) explains, it was recorded that starting in 1990, the Indonesian government issued a ban on the use of sea turtles nationally. This prohibition makes the tradition of using turtles categorized as an act against the law. Seeing the dangers of illegal trade in reducing the number of turtle species in the Bali province, WWF is trying to overcome this crime by collaborating with the Bali government in socialization and training to maintain the number of turtle species in Bali (Pardede \& Yealta, 2013). Some details concerning government regulation are as follows:

"Leatherback turtles are protected based on the Decree of the Minister of Agriculture No.327 / Kpts / Um / 5/1978; The loggerhead and lekang turtles are protected based on the Decree of the Minister of Agriculture No.716 / Kpts / Um / 10/1980; Hawksbill and Flatback Turtles are protected based on the Decree of the Minister of Forestry No.882 / Kpts-II / 1992, and Green Turtles are included in the 6 types of turtles that are protected under PP No.7 / 1999 concerning the preservation of plants and animals. National law no. 5 of 1990 and PP.NO.7 and 8 of 1990 concerning the conservation of endangered species (turtles)".

A research done by an academic community in 1991 was discussed by Sudiana (2010), this research states that Balinese people each year consume 17,985 turtles, equal to $24,730 \mathrm{~kg}$. This indicates that Bali is highlighted as a province where people exploit sea turtles excessively (non-sustainable use). In correlation with this statement, the government, non-governmental organiation and other environmentalists have taken legal steps or formal initiatives to stop the usage of turtles in the form of trade and consumption in Bali. The lifestyle of people exploiting turtles excessively is a setback to ensure awareness being raised in order to conserve the population of sea turtles (LópezBarrera et al., 2016). The effort to better the status of sea turtles with only law enforcement is not enough, in fact, the willingness of the community to abandon their lifestyle of using sea turtles in a large scale is key to reduce bad habits that threaten sea turtles to begin with.

\section{Turtle Conservation}

Sea turtle conservation aims to prevent extinction, eliminate unsustainable use, and educate society regarding the purpose of this species (Gangal et al., 2021; Quesada-Rodríguez et al., 2021; Riskas et al., 2018). This line of conservation has become a priority in Indonesia and is being implemented by most of the province. Indonesian law enforcement is keen to uphold sea turtle conservation as their priority, and facts supporting this statement (Table 2).

According to the Indonesian conservation map by Udayana University (UNUD) Bali and WWF-Indonesia, there were 42 cases of sea turtles traded illegally and thwarted by 
Indonesian law enforcement officials in 20022009, in which 39 cases are Bali related. Furthermore, 2705 green turtles were successfully secured as evidence, while 2451 $(90.6 \%)$ green turtles were successfully released into the sea, the remaining $254(9.4 \%)$ green turtles were found dead when it had happened. Further successful findings are in 2009, when law enforcement was able to thwart 3 cases of sea turtle smuggling in Sinjai, 32 cases in Tanjung Benoa, 6 cases in Bali and 28 cases in Dompu (NTB) (WWF-Indonesia, 2020).

Although law enforcement plays an important role in sea turtle conservation, it has not been the only attempt to protect these species. There are plenty of sea turtle conservation, one of many is in context with resorts and tourism which has brought economic success. Bintan Resort is located in Riau and has been carrying out this program since 2004. In 2005, Nanyang Technological University and National University Singapore helped Bintan Resort educate the staff about turtle breeding. Lessons were also given to local communities concerning the importance of turtle population and the coastal environment. In line with techniques related to captivity, the success rate of hatching eggs also increases with a variation between 74\%-98\% (Winata et al., 2010). In 2009, the community of the Bintan Resort built a breeding ground in the local village. These efforts have succeeded in reducing the rate of turtle egg harvesting by the community from $91 \%$ in 2004 to $20 \%$ in 2009. Bintan Resort has begun to adopt the principle of releasing hatchlings directly when the sun begins to set. This activity is carried out based on the fact that Bintan Resort keeps data on the orientation of the beach where the turtle eggs hatch, so that they can return again after reaching adulthood. The practice of captive breeding and maintenance of hatchlings prior to the release is known to influence hatchling orientation and survival instincts. Moreover, because of the variation in the pattern of Indonesian Cross Flow each season, releasing hatchlings after being raised may change their pattern of spatial distribution. This level of conservation has proven to be economically beneficial due to the increase of hotel occupancy rates at the Bintan Resort. This hatchling release conservation program has become the number one conservation program to be awaited by tourists (Budiantoro et al., 2019).

Hatching process are impacted by the environment in which the egg is located (Madden et al., 2008). Factors that determine sea turtle eggs to hatch are temperature, gas exchange, embryonic development, water, and altered beaches. During the course of incubation, the embryo grows inside the egg from a few cells at the beginning to a self-sufficient organism at hatching 50 to 80 days later. How embryonic growth may be influenced by the environment or by exchange with the environment is unknown, however, embryonic growth is unlikely to be independent of the environment. Unfortunately, the knowledge of developmental and regulatory physiology inside the egg is rudimentary for all reptile egg especially sea turtles. At this point, temperature, gas exchange, and water are key components to ensure a successful hatching during the hatching period (Ackerman 2017). According to Maulana (2017), the depth of sea turtle eggs are also a factor ensuring successful hatching. As emphasized by Kushartono (2014) $15,20,25 \mathrm{~cm}$ depth obtains a safe temperature for this process which is around 25-27 degrees Celsius. During this hatching process, the mother sea turtle will not be there as these hatchlings independently head to the ocean and repeat the cycle of life (Budiantoro et al., 2019).

One of the conservation organizations in Bali, TCEC Serangan, has nurtured sea turtle eggs semi-natural and hatchlings, as well as providing life support to sick sea turtles. Similar to Bintan Resort, Turtle Conservation and Education Center (TCEC) has incorporated hatchling release as a part of their conservation program that attracts tourists who visit Serangan, Bali (Ginting et al., 2020). Ways to protect and preserve sea turtles to continue their life in the wild is to nurture their eggs and hatchlings (Ceriani \& Wyneken, 2008). A part of this article is to provide indication and explanation as 
Table 1. Trend of successful and unsuccessful sea turtle hatchings in Bali

\begin{tabular}{cccc}
\hline Year & Amount of Eggs & Successful Hatchings & Unsuccessful Hatchings \\
\hline 2016 & 6,605 & 27 & 6,578 \\
2017 & 11,029 & 1,976 & 9,053 \\
2018 & 21,306 & 12,497 & 8,809 \\
2019 & 23,400 & 11,652 & 10,979 \\
\hline
\end{tabular}

Table 2. Comparison of potential analysis with supporting evidence for ecotourism incidents in TCEC, Bali

\begin{tabular}{|c|c|c|}
\hline Potential & Parameters & Supporting Evidence: events with \\
\hline $\begin{array}{l}\text { Positive socio- } \\
\text { economic impact }\end{array}$ & Increase in employment & New jobs at ecotourism Green Island. \\
\hline Social learning & $\begin{array}{l}\text { Carry out joint action or } \\
\text { research }\end{array}$ & $\begin{array}{l}\text { 1. Involvement of research institutes or } \\
\text { universities in TCEC. } \\
\text { 2. MoU TCEC and BKSDA Bali on a turtle } \\
\text { conservation program through a hatchling } \\
\text { rearing demonstration plot. } \\
\text { 3. Monitoring and evaluation as a form of single } \\
\text { cycle learning is carried out by BKSDA Bali. }\end{array}$ \\
\hline Conservation & $\begin{array}{l}\text { Activities or programs that } \\
\text { are carried out open to the } \\
\text { public. }\end{array}$ & $\begin{array}{l}\text { 1. Release of hatchlings with local communities } \\
\text { and tourists. } \\
\text { 2. Monitoring turtle eggs in adjusted } \\
\text { circumstances in order to increase the number } \\
\text { of successful egg hatching. } \\
\text { 3. The number of eggs produced each year has } \\
\text { increased. } \\
\text { 4. TCEC Serangan conservation location which } \\
\text { is open to the public (Site seeing). }\end{array}$ \\
\hline $\begin{array}{l}\text { Raising public } \\
\text { awareness The }\end{array}$ & $\begin{array}{l}\text { Implementation of security } \\
\text { measures and community } \\
\text { involvement. }\end{array}$ & $\begin{array}{l}\text { 1. Observation posts along the coast are useful } \\
\text { for observing if there are turtles that come to } \\
\text { the land to lay eggs and save their eggs from } \\
\text { natural predators and humans who want to } \\
\text { take them. } \\
\text { 2. Community and tourist involvement in giving } \\
\text { donations and purchasing hatchlings to be } \\
\text { released. }\end{array}$ \\
\hline
\end{tabular}

for the birth and death rate trend of hatchlings in Serangan and Saba Beach, Denpasar Bali from 2016 to 2019. The data obtained is secondary data cited from Suriyani, (2020) and Harnino et al., (2021) in which the two studies are correlated in carrying out the management and protection of sea turtles in the Turtle Conservation and Education Center (TCEC) and Saba Beach, Bali. A table regarding the successful hatchling rates trends from 2016 to 2019 (Table 1).
Overall, this data and statements provide a good indication of sea turtles sustainability, meaning, sea turtle egg conservation is developing every year. This helps restore balance concerning the number of sea turtles in Bali. Although hatching methods in Saba beach is not stated, a method adapted by TCEC that brought this success is adapting a semi natural nesting area. However, monitoring temperature and other factors that result in hatching failure needs to be considered and further studies, in 


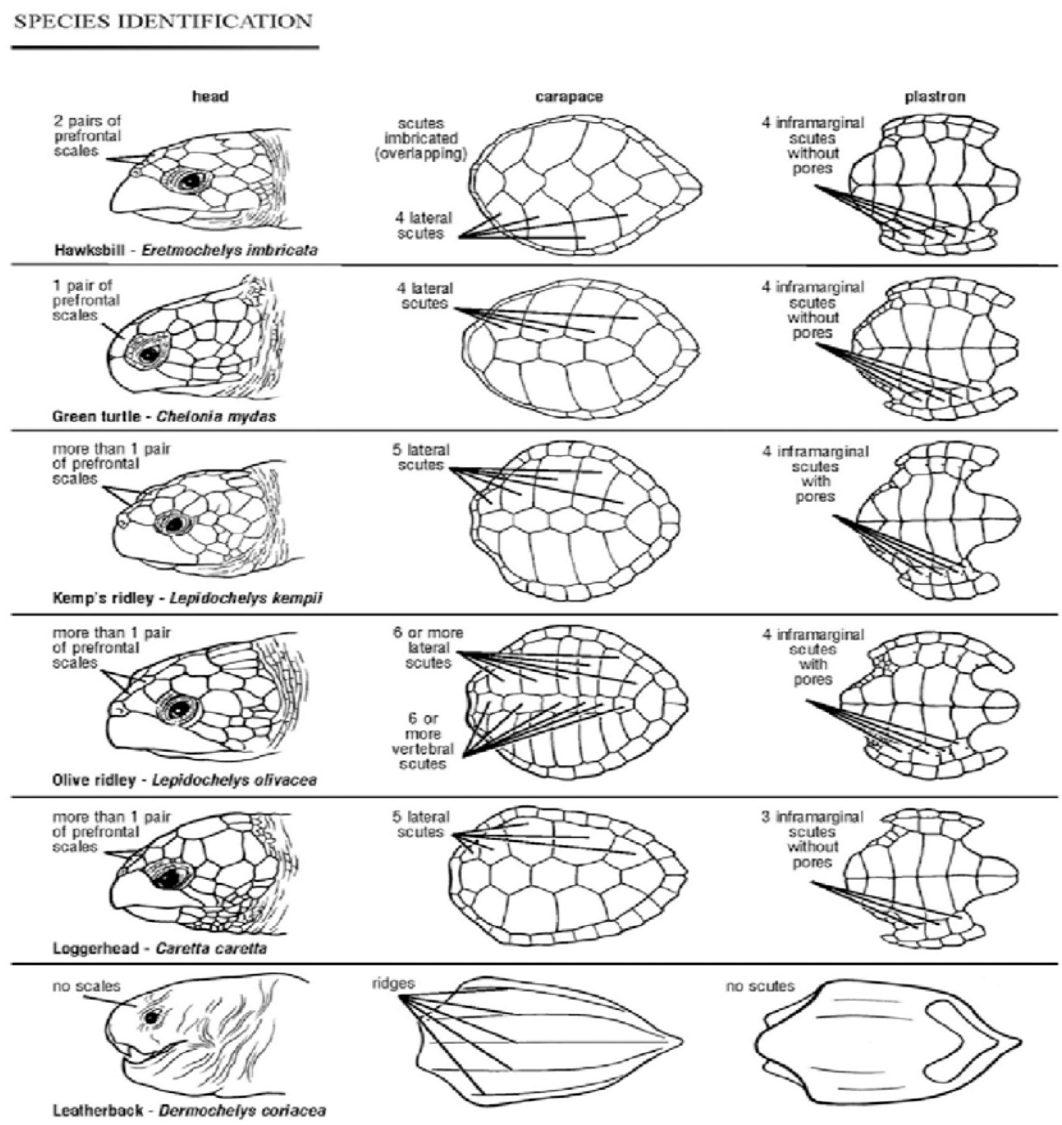

Figure 1. Species identification guide to sea turtles found in U.S. territorial waters. Source of figure courtesy of Dawn Witherington and Jeanette Wyneken (Wyneken, 2015).

order to avoid the increase of failed hatchings. Semi-natural in vitro conservation has potential to ensure monitoring during the hatching period.

Alfikri et al. (2019) conducted a research focusing on semi-natural hatching program and correlating between the numbers of eggs incubated and hatching success. This specific program was conducted in a time period of 7 years from 2012-2019. Semi-natural hatching programs has several processes, the first process is egg collection, in which these eggs are carefully placed in a plastic wrap and brought to the location of the semi-natural hatchery. Secondly, all eggs are placed into an artificial hole carefully prepared to obtain a suitable depth and temperature, this hole is made out of sand. The hole was 70 to $80 \mathrm{~cm}$ deep with a temperature around $27-30^{\circ} \mathrm{C}$, this condition is safe from sea water flooding. There are two holes containing a number of eggs not uniformly. The result of this study revealed a high success hatchery rate about $50.59 \%$ (of the 85 incubated eggs), $93.06 \%$ (of the 72 incubated eggs); with a total hatchery success rate reaching $77.26 \%$. This study indicates the biggest factor of failed hatching are mainly due to time consuming process during egg transfer, eggs from different parental combined in one artificial hole, and a large quantity of eggs incubated in one nest hole.

Another side to analyze is the factor of temperature. As mentioned by Ackerman (2017) temperature plays an important role making sure embryonic development won't experience disturbance to which hatching failure might occur. In the study of Alfikri, the eggs are placed not uniformly age and parental wise. Meaning, the temperature adjusted might not be suitable for all eggs in the same artificial nest that ultimately leads to hatching failure.

To compare this Alfikri's study and the overall trend of successful and unsuccessful sea turtle hatchings in Bali, the main problem of temperature that lead to hatching failure in Bali is manageable by the research conducted by Alfikri. It is revealed that temperature can be 
controlled by the depth of the artificial nest also emphasized by Maulana (2017). Therefore, semi-natural hatchery program promising a $77.26 \%$ indicates a good result. Based on the result conducted by Alfikri et al. (2019) the semi-natural hatching program are recommended to be implemented as the main alternative is to avoid natural predators and illegal hunting. Although, in depth research regarding Seminatural in vitro conservation should be done in order to control and optimal level of temperature, salinity, $\mathrm{pH}$ level, and humidity.

\section{The Potential of Turtle Ecotourism}

According to Alfinda, (2017), turtle breeding ecotourism is a tourism spot that can shelter turtle conservation activities as well as educational activities in the form of research. Rismang et al., (2018) explained that prior to conservation, sea turtles were used as raw material to support human social life which led to a decrease in its population. The catalysts for the extinction of turtles are destruction of nesting habitats, coastal abrasion, and turtle food that has been exploited on a large scale (Siqueira-Silva et al., 2020; Vásquez-Carrillo \& Peláez-Ossa, 2021; Vélez-Rubio et al., 2018). Kuenzi \& McNeely, (2008) continues by discussing ecotourism, namely nature-based tourism, as an option in promoting a unique and authentic environment, as well as being a tourism site. Ecotourism serves as a means of education, tourism, conservation, and harmonizing the economic needs of the community with the interest of conserving natural resources (Nahill, 2021). The potential and utilization of sea turtles as an ecotourism attraction can be seen from their egg laying behavior and foraging behavior (Dushani et al., 2021; Mobaraki et al., 2020). This can be supported by binocular facilities and interpreting services to increase visitor knowledge. The example of ecotourism will be useful in terms of economy, education and conservation to keep sea turtle life sustainable.

Based on the function of ecotourism, its potential also has an impact on socio-economy, education, conservation, and the increase of public awareness (Kiper, 2013). The following is a table of a study analysis from the research of Amelia et al., (2019) and Ginting et al., (2020) regarding the potential for ecotourism in TCEC Serangan, Bali that is supported by evidence of incidents (Table 2).

Based on this analysis, the theory of ecotourism potential according to Alfinda, (2017) is evident in TCEC Serangan. Even so, further research is needed in other turtle conservation sites such as Kurma Asih, BSTS, Saba Asri, and Deluang Sari. Research on the potential of ecotourism in the coming years is also needed to ensure that further conservation activities can incline to reach its potential.

\section{DNA Barcoding}

There are numerous ways to identify species, physical or external identification, being the most common techniques. According to Wyneken (2015) sea turtle identification, from external characters, is mainly based upon the scales on the head, from the jaws, the number of claws on the foot, and the number and arrangements of the plates or scutes on the shell. These characteristics varies between species. A detailed differentiation of this characteristics are shown in the image presented in Jeanette Wynekens' book (Figure 1).

Sea turtles are trafficked to maintain social lifestyle for example, the meats are cooked and shells are made into decoration all in one purpose to sell to communities. This specific case demolishes the capability to identify sea turtle species by its external characteristics. Because of this situation, DNA Barcoding plays an important role to uphold the law against sea turtle trafficking. According to Trivedi et al., (2016) DNA barcoding is an important tool in forensics and wildlife conservation. This can be used to identify endangered turtles by valuing illegally traded turtle meat, carcasses or eggs. One of the essential requirements of DNA barcodes is the collection and maintenance of samples as voucher specimens, which allows a reliable way of correcting the identification of the species from which data is accumulated. Coupon specimens provide permanent documentation for investigations of marine 
biodiversity. DNA stem coding has great uses in the field of taxonomy (Ajmal Ali et al., 2014). In a separate study, DNA barcoding was carried out for sea turtles that are globally endangered. This study shows that DNA barcoding is not only a capable tool for species identification, but can also play an important role in wildlife forensics and conservation genetics (Yang et al., 2018).

Results of the research of Madduppa et al., (2019) regarding turtle DNA barcodes and their implications for conservation managers have developed protocols that allow identification of tissue samples of different qualities. The $719 \mathrm{bp}$ fragments of the analyzed control region showed a high percentage similar to the GenBank CO1 sequence with $99 \%-100 \%$. Four sea turtle species were identified among the samples, namely Chelonia mydas (4 samples), Lepidochelys olivacea (9 samples), Eretmochelys imbricata (2 samples) and Dermochelys coriacea (1 sample). This research has succeeded in strengthening the network of different sample sources by using the target DNA of the control area and therefore will be of benefit to the conservation of turtle management in Indonesia.

Sea turtles are migrating marine animals and the travel route of each species varies. Based on a research conducted by Mansfield et al. (2021), it was verified that (i) oceanic-stage green turtles travel to and remain within oceanic waters, (ii) often depart the Gulf Stream and North Atlantic Subtropical Gyre currents, orienting towards waters associated with the Sargasso Sea; (iii) remain at the sea surface, using thermally beneficial habitats that promote growth and survival of young turtles; (iv) green turtles orient differently compared to same stage loggerhead turtles. In order maintain the population and status of sea turtles, the origin of the trafficked turtle must be known in a geographical stand point. Knowing where these turtles are treated illegally, will make it possible for law enforcements to enforce the law. DNA Barcoding is a solution to this matter.

A research conducted by Abdalwahhab et al., (2020) revealed that DNA Barcoding was successfully carried out to identify 7 different fish families and 3 orders, by applying the sequencing of the cytochrome oxidase subunit 1 mitochondrial gene (COI) in the Northern Red Sea. This study revealed a $98 \%$ success of species identification implementing DNA Barcoding. This study emphasized more works using the applied analyses can be strongly recommended to aid proper conservation and management of economic aquatic species especially in the Red Sea. Another supporting research conducted by Pertiwi et al., (2020), aims to investigate trafficked turtles. This research also aims to identify the species and origin of the turtle population that is caught and traded on the illegal market in Bali, Indonesia. The results of Pertiwi et al., (2020) is a sample of turtles collected from illegal trade in Bali where the species are identified as Chelonia mydas (green turtle) and Lepidochelys olivacea (Olive Ridley sea turtle). This finding revealed that the illegal trade of sea turtles in 2020 still occurs in Bali, and the information must be given to the Indonesian government. Monitoring and protecting sea turtles in Bali must be a high priority because Bali is known as a center for illegal trade of sea turtles, and the exploitation of turtles in Bali has an impact on turtle population in other locations. This study can increase the awareness of turtle conservation and law enforcement for the exploitation of sea turtles. The efficiency of law enforcement and conservation itself can be increased using the DNA Barcoding method.

\section{CONCLUSION}

Based on the description of the results and discussion, it can be concluded that the status of turtles in Bali is threatened with extinction and until 2020 there are still illegal trades of sea turtles, which can be detected using the DNA Barcoding method. The trend of turtle conservation in Indonesia is the release of hatchlings during the sunset, where monitoring of hatchlings until they are ready to hatch is done semi-naturally. This trend has succeeded to increase the production of hatchlings each year, namely in 2016 as many as 6,605 to 2019 as many as 23,400 hatchlings. This helps restore 
the balance of sea turtle population in Indonesia, especially Bali. During 2019, numbers of failed hatchlings inclines due to inconsistent sand temperature, which should be monitored closely in the future. A study analysis of comparing ecotourism potential with supporting incidents at TCEC Serangan is evident. Further studies are required to ensure accuracy in other Bali conservation sites. DNA Barcoding is proven to be reliable in increasing awareness of turtle conservation and law enforcement for the exploitation of sea turtles. This method can be implemented in the future to support the effectiveness of conservation and law enforcement in Bali. This paper emphasize recommendations regarding raising awareness in order to change mindsets of exploiting sea turtles, semi-natural hatchery programs to maintain external environmental conditions in order to achieve successful hatchings, sea turtle conservation incorporating ecotourism to benefit the conservation site itself in order to launch new conservation programs as well as an economical benefit to the society, and DNA Barcoding as a technological solution towards enforcing the law of sea turtle trafficking.

\section{ACKNOWLEDGEMENT}

We thank the Biology Study Program, Faculty of Health, Science and Technology, Dhyana Pura University, Bali, that have support this review's writing. We would like to thank the Turtle Conservation and Education Center (TCEC), Serangan, Bali, that have provide suggestions and input in completing our review data.

\section{REFERENCES}

Abdalwahhab, O., Galal-Khallaf, A., Saber, S. A. E. L., Osman, A. G., \& MohammedGeba, K. (2020). A case study for application of DNA barcoding in identifying species and genetic diversity of fish from the Suez city market, Egypt. Aquatic Living Resources, 33.
Ackerman, R.A. (1996), "The Nest Environment and the Embryonic Development of Sea Turtle", The Biology of Sea Turtles, 1st Editio., Taylor \& Francis Group, p. 24.

Adi Eti Harnino, T. Z., Parawangsa, I. N. Y., Sari, L. A., \& Arsad, S. (2021). Effectiveness of Sea Turtle Conservation Management at the Turtle Conservation and Education Center of Serangan, Denpasar Bali. Journal of Marine and Coastal Science, 10(1), 18.

Ajmal Ali, M., Gyulai, G., Hidvégi, N., Kerti, B., Al Hemaid, F. M. A., Pandey, A. K., \& Lee, J. (2014). The changing epitome of species identification - DNA barcoding. Saudi Journal of Biological Sciences, 21(3), 204-231.

Alfinda, F. (2017). Kawasan Ekowisata Penangkaran Penyu di Desa Sebubus, Kabupaten Sambas. JMARS: Jurnal Mosaik Arsitektur, 5(2).

Alfikri, M. D., Nurhasanah, A. H., Putranto, P. H., Auliadin, F., \& Tobing, I. S. (2020). Hatching Success of Green Turtle (Chelonia mydas) in Semi-Natural Hatchery Citirem Beach, Cikepuh Wildlife Reserve, Sukabumi, West Java. International Conference on Biodiversity for Life: Sustainable Development of Indonesia Biodiversity.

Amelia, C., Paturusi, S. A., \& Merit, I. N. (2019). Adaptive Governance System through Multi-Stakeholder Partnerships for Natural Resource Conservation in Serangan Island, Denpasar City. ECOTROPHIC: Jurnal Ilmu Lingkungan (Journal of Environmental Science), 13(1), 85.

Ario, R., Wibowo, E., Pratikto, I., \& Fajar, S. (2016). Pelestarian Habitat Penyu Dari Ancaman Kepunahan Di Turtle Conservation And Education Center 
(TCEC), Bali. Jurnal Kelautan Tropis, 19(1), 60.

Astiani, D., Mujiman, M., \& Rafiastanto, A. (2017). Forest type diversity on carbon stocks: Cases of recent land cover conditions of tropical lowland, swamp, and peatland forests in West Kalimantan, Indonesia. Biodiversitas Journal of Biological Diversity, 18(1).

Ayuningtyas, I., Kushartono, E. W., \& Redjeki, S. (2019). Identifikasi Jamur Pada Tukik Lepidochelys olivacea , Eschscholtz , 1829 ( Reptilia: Cheloniidae ) Di Turtle Conservation And Education Center Bali. Journal of Marine Research, 8(2), 157-167.

Budiantoro, A., Retnaningdyah, C., Hakim, L., \& Leksono, A. S. (2019). The Sustainable Ecotourism Potential Development With Special Reference to Oliveridley Sea Turtle ( Lepidochelys olivacea) Along Bantul Beaches, Indonesia. IOP Conference Series: Earth and Environmental Science, 391, 012069.

Ceriani, S. A., \& Wyneken, J. (2008). Comparative morphology and sex identification of the reproductive system in formalin-preserved sea turtle specimens. Zoology, 111(3), 179-187.

Dushani, S. N., Aanesen, M., \& Vondolia, G. K. (2021). Balancing conservation goals and ecotourism development in coastal wetland management in Sri Lanka: A choice experiment. Ocean \& Coastal Management, $210,105659$.

Espinoza, E. O., Moore, M. K., Hamlin, B. C., Baker, B. W., \& Espinoza, A. J. (2021). Forensic characterization of sea turtle oil by ambient ionization mass spectrometry: Caretta caretta, Chelonia mydas, Dermochelys coriacea, Eretmochelys imbricata, Lepidochelys kempii, and Lepidochelys olivacea. Forensic Science
International: Animals and Environments, 1,100008 .

Gangal, M., Gafoor, A.-B., D’Souza, E., Kelkar, N., Karkarey, R., Marbà, N., Arthur, R., \& Alcoverro, T. (2021). Sequential overgrazing by green turtles causes archipelago-wide functional extinctions of seagrass meadows. Biological Conservation, 260, 109195.

Ginting, F. A. B., Djunaedi, A., \& Ario, R. (2020). Pengaruh Komposisi Pakan Terhadap Laju Pertumbuhan Tukik Penyu Lekang di Serangan, Bali. Journal of Marine Research, 9(4), 362-368.

Guebert, F. M., Barletta, M., \& da Costa, M. F. (2013). Threats to sea turtle populations in the Western Atlantic: poaching and mortality in small-scale fishery gears. Journal of Coastal Research, 65, 42-47.

Hamann, M., Godfrey, M., Seminoff, J., Arthur, K., Barata, P., Bjorndal, K., Bolten, A., Broderick, A., Campbell, L., Carreras, C., Casale, P., Chaloupka, M., Chan, S., Coyne, M., Crowder, L., Diez, C., Dutton, P., Epperly, S., FitzSimmons, N., ... Godley, B. (2010). Global research priorities for sea turtles: informing management and conservation in the 21st century. Endangered Species Research, 11(3), 245269.

Hill, M. K., Monroe, M. C., Ankersen, T. T., Carthy, R. R., \& Kay, T. A. (2019). Conservation easements and coastal armoring: Protecting sea turtle nesting habitat through property ownership. Ocean \& Coastal Management, 182, 104944.

Kiper, T. (2013). Role of Ecotourism in Sustainable Development. In Advances in Landscape Architecture. InTech. 
Kuenzi, C., \& McNeely, J. (n.d.). Nature-Based Tourism. In Global Risk Governance (pp. 155-178). Springer Netherlands.

Kushartono, E. W., Susilo, E. S., \& Fatchiyyah, S. (2014). Pengaruh Selang Waktu Peletakkan Terhadap Keberhasilan Penetasan Telur Penyu Hijau (Chelonia mydas L.) (Effect of Planting Time on Egg Hatching Success of Green Turtle (Chelonia mydas L.). ILMU KELAUTAN: Indonesian Journal of Marine Sciences, 19(3), 159.

López-Barrera, E. A., Reis, E., Vilaça, S. T., \& Vargas, S. (2016). Genetics and Conservation of Sea Turtles. In J. M. Rguez-Baron, M. M. Lara-Uc, \& R. Riosmena-Rodriguez (Eds.), Advances in Research Techniques for the Study of Sea Turtles. Nova Science Publishers.

Luschi, P. (2013). Long-Distance Animal Migrations in the Oceanic Environment: Orientation and Navigation Correlates. ISRN Zoology, 2013, 1-23.

Madden, D., Ballestero, J., Calvo, C., Carlson, R., Christians, E., \& Madden, E. (2008). Sea Turtle Nesting as a Process Influencing a Sandy Beach Ecosystem. Biotropica, 40(6), 758-765.

Madduppa, H. H., Bahri, S., Subhan, B., Anggraini, N. P., Ohoiulun, H., Abdillah, T., Arafat, D., Santoso, P., \& Sangadji, I. M. (2019). DNA barcoding of sea turtles (Dermochelyidae and Cheloniidae) and its protocol using different tissues quality: Implication to conservation managers. IOP Conference Series: Earth and Environmental Science, 278(1).

Maharani, V., Hamid, H., \& Bathara, L. (2016). Multiplier Effect of Sea Turtle Conservation Working Toward. Jurnal Online Mahasiswa Fakultas Perikanan Dan Ilmu Kelautan Universitas Riau, 3(2), 1-8.
Mansfield, K. L., Wyneken, J., \& Luo, J. (2021). First Atlantic satellite tracks of 'lost years' green turtles support the importance of the Sargasso Sea as a sea turtle nursery. Proceedings of the Royal Society B: Biological Sciences, 288(1950), rspb.2021.0057.

Mansula, J. G., \& Romadhon, A. (2020). Analisis Kesesuaian Habitat Peneluran Penyu Di Pantai Saba, Gianyar, Bali. Juvenil:Jurnal Ilmiah Kelautan Dan Perikanan, 1(1), 8-18.

Maulana, R., Adi, W., \& Muslih, K. (2017). Kedalaman Sarang Semi Alami Terhadap Keberhasilan Penetasan Telur Penyu Sisik (Eretmochelys imbricata) Di Penangkaran Tukik Babel, Sungailiat. Akuatik: Jurnal Sumberdaya Perairan, 11(2), 51-57.

Mazaris, A. D., Matsinos, G., \& Pantis, J. D. (2009). Evaluating the impacts of coastal squeeze on sea turtle nesting. Ocean \& Coastal Management, 52(2), 139-145.

Mazaris, A. D., Schofield, G., Gkazinou, C., Almpanidou, V., \& Hays, G. C. (2017). Global sea turtle conservation successes. Science Advances, 3(9), e1600730.

Mobaraki, A., RastegarPouyani, E., Kami, H. G., \& Khorasani, N. (2020). Population study of foraging Green sea turtles (Chelonia mydas) in the Northern Persian Gulf and Oman Sea, Iran. Regional Studies in Marine Science, 39, 101433.

Nahill, B. (2021). Sea Turtle Ecotourism. In Sea Turtle Research and Conservation (pp. 95104). Elsevier.

Pardede, M. T., \& Yealta, D. (2013). Upaya World Wide Fund For Nature (WWF) Dalam Mengatasi Perdagangan Penyu Ilegal Di Provinsi Bali Tahun 2008-2013. Jurnal Online Mahasiswa Fakultas Perikanan Dan Ilmu Kelautan Universitas Riau, 2(2). 
Pertiwi, N. P. D., Suhendro, M. D., Yusmalinda, N. L. A., Putra, I. N. G., Putri, I. G. R. M., Artiningsih, E. Y., Al-Malik, M. D., Cahyani, N. K. D., \& Sembiring, A. (2020). Forensic genetic case study: Species identification and traceability of sea turtle caught in illegal trade in Bali, Indonesia. Biodiversitas Journal of Biological Diversity, 21(9).

Prihadi, D. J., Shofiyullah, A., \& Dhahiyat, Y. (2018). Marine tourism and the locations of protected turtles on Sukamade Beach, Meru Betiri National Park, East Java. IOP Conference Series: Earth and Environmental Science, 137, 012050.

Quesada-Rodríguez, C., Orientale, C., DiazOrozco, J., \& Sellés-Ríos, B. (2021). Impact of 2020 COVID-19 lockdown on environmental education and leatherback sea turtle (Dermochelys coriacea) nesting monitoring in Pacuare Reserve, Costa Rica. Biological Conservation, 255, 108981.

Rice, N., Hirama, S., \& Witherington, B. (2021). High frequency of micro- and meso-plastics ingestion in a sample of neonate sea turtles from a major rookery. Marine Pollution Bulletin, 167, 112363.

Riskas, K. A., Tobin, R. C., Fuentes, M. M. P. B., \& Hamann, M. (2018). Evaluating the threat of IUU fishing to sea turtles in the Indian Ocean and Southeast Asia using expert elicitation. Biological Conservation, 217, 232-239.

Rismang, R., Rauf, A., \& Rustam, R. (2018). Kajian Pengembangan Kawasan Konservasi Penyu Sebagai Kawasan Ekowisata Di Dusun Tulang Desa Barugaiya Kabupaten Kepulauan Selayar. Jurnal Pendidikan Teknologi PPertanian, 4.

Robinson, N. J., \& Paladino, F. V. (2013). Sea Turtles. In Reference Module in Earth
Systems and Environmental Sciences. Elsevier.

Siqueira-Silva, I. S., Arantes, M. O., Hackradt, C. W., \& Schiavetti, A. (2020). Environmental and anthropogenic factors affecting nesting site selection by sea turtles. Marine Environmental Research, 162, 105090.

Stronza, A. L., Hunt, C. A., \& Fitzgerald, L. A. (2019). Ecotourism for Conservation? Annual Review of Environment and Resources, 44(1), 229-253.

Sudiana, I. G. N. (2010). Transformasi Budaya Masyarakat Desa Serangan Di Denpasar Selatan Dalam Pelestarian Satwa Penyu. Bumi Lestari Journal of Environment, 10(2), 311-320.

Suraeda, R. Y., Sunaryo, S., \& Kushartono, E. W. (2018). Laju Pertumbuhan Spesifik Tukik Penyu Lekang ( Lepidochelys olivacea ) dengan Pemberian Pakan Buatan Yang Berbeda di Turtle Conservation And Education Center, Bali. Journal of Marine Research, 7(3), 185-192.

Suriyani. (2020). Ribuan Tukik Menetas di Pantai Saba. Mongabay. https://www.mongabay.co.id/2020/08/08/rib uan-tukik-menetas-di-pantai-saba/

Tisdell, C. A., \& Wilson, C. (2002). Ecotourism for the survival of sea turtles and other wildlife. Biodiversity and Conservation, 11(9).

Trivedi, S., Aloufi, A. A., Rehman, H., Saggu, S., \& Ghosh, S. K. (2016). DNA barcoding: Tool for assessing species identification in Reptilia. Journal of Entomology and Zoology Studies JEZS, 332(41), 332-337.

Vásquez-Carrillo, C., \& Peláez-Ossa, M. (2021). Insights into the ecology of sea turtles and the fisheries of eastern Guajira from the 
traditional knowledge of fishermen. Fisheries Research, 238, 105915.

Vélez-Rubio, G. M., Teryda, N., Asaroff, P. E., Estrades, A., Rodriguez, D., \& Tomás, J. (2018). Differential impact of marine debris ingestion during ontogenetic dietary shift of green turtles in Uruguayan waters. Marine Pollution Bulletin, 127, 603-611.

Williams, J. L. (2021). Working With Smallscale Fishers in the Southwest Indian Ocean to Understand Illegal Take, Trade, and Use of Sea Turtles. In Sea Turtle Research and Conservation (pp. 123-131). Elsevier.

Wilson, C., \& Tisdell, C. (2003). Conservation and Economic Benefits of Wildlife-Based Marine Tourism: Sea Turtles and Whales as Case Studies. Human Dimensions of Wildlife, 8(1), 49-58.

Winata, C. K., Samanya, R., Febriana, R., Wahyuni, H., Asfari, M., \& Rofiq, M. (2010). Community Based Approach to Turtle Conservation in Bintan: The first step. In International Symposium on
Integrated Coastal Management for Marine Biodiversity in Asia, (Issue January).

Wiradana, P. A., Widhiantara, I. G., Pradisty, N. A., \& Mukti, A. T. (2021). The impact of COVID-19 on Indonesian fisheries conditions: opinion of current status and recommendations. IOP Conference Series: Earth and Environmental Science, 718(1), 012020.

Wyneken, J. (2001). The anatomy of sea turtles Nervous System. Research Gate, December, 52.

WWF-Indonesia. (2020). Peta Konservasi Penyu di Indonesia. http://awsassets.wwf.or.id/downloads/peta penyu_depan_belakang_hires_1.pdf

Yang, F., Ding, F., Chen, H., He, M., Zhu, S., Ma, X., Jiang, L., \& Li, H. (2018). DNA Barcoding for the Identification and Authentication of Animal Species in Traditional Medicine. Evidence-Based Complementary and Alternative Medicine, 2018, 1-18. 